of the gaily coloured agricultural machines. An important advance in the last few years has been the introduction of the fluorescent tube as a light source; its extended area and low brightness result in a reduction of hard shadows and the absence of glare, while through the choice of the fluorescent material, the colour can be controlled very successfully. A good approximation to daylight can be obtained, and, through the employment of daylight fluorescent lamps, the illuminating engineer can mix artificial light with daylight without introducing the disturbing rsthetic appearance noticeable when ordinary tungsten lamps are used in a room which is simultaneously being illuminated by daylight.

Questions were asked about the extent to which the design of lighting installations should attempt to simulate daylight, both in its colour and distribution ; the evidence goes to show that generally we prefer the lighting to which we have been accustomed, so that any tendency towards one particular form of installation has no justification from experience. The design of windows and daylighting is largely an architectural problem, and for illuminating engineers to arrange their lighting fixtures to give an imitation of window lighting would impose an unnecessary, artificial restriction on the freedom they otherwise possess.

Mr. G. H. Giles, who spoke from the point of view of the optician, claimed that the optician is in a position to act as a clearing station for the specialist -the physicist, the illuminating engineer, the medical practitioner. There is a very obvious need for close attention to refractive errors among the workers in industry, since statistics, many from the United States, show that the percentage of workers with visual defects is very high. Correction of the defects with spectacles leads to roughly 20 or 30 per cent increased production, with a corresponding decrease in the discomfort and fatigue of the worker. Naturally, there is a greater tolerance for defects in one type of work than in another, but there are occupations where visual aids are desirable, even though the vision of the worker is normal. Thus, where prolonged close work is involved, it has been found that much of the strain can be removed if the worker wears a pair of glasses which combine a lens and prism for each eye. In this way most of the need for excessive focusing and excessive convergence of the two eyes can be avoided, with a consequent lessening of the muscular effort; Weston and Adams have shown that great benefits have resulted from the use of such aids, leading to a marked reduction in fatigue and eyestrain, and a significant increase in output. During the discussion, the value of spectacles of this type was especially emphasized in the case of prolonged near work and it was considered that they could be employed on a far wider scale than is the case at present.

Tests for eye defects other than refractive errors, such as colour blindness and defective night vision, may also be needed. Recently, a number of workers at a factory claimed to have poor night vision, but when tests proved them to be normal, it transpired that they had hoped in this way to avoid fire-watching duties! Opticians also deal with protective glasses against damage from different radiations and from other hazards such as flying chips and molten substances. Finally, Mr. Giles referred to a scheme inaugurated by the Joint Council of Qualified Opticians for testing the vision of factory workers, whereby a rota of opticians is made available for the purpose. A valuable service was being performed in this way before the War, but during the War the scheme has proved even more useful and has been officially adopted for Royal Ordnance Factories.

The routine eye examination carried out by opticians under the scheme of the Joint Council of Qualified Opticians was described in some detail by Mr. R. A. Rider. As the testing of each patient may occupy at least thirty minutes, the time required to deal with a works in which, say, 20,000 persons are employed is very great. The tests may therefore have to be directed in the first place to those who show symptoms of ocular defect.

In the final paper Dr. H. Lowery broached a rather different aspect of the subject when he referred to the part played by the eye during training for such activities as carpentry, metal work and other technical handicrafts. This is very much a question of securing proper co-ordination between hand and eye and it is important, especially at the present time, to know why and how training improves the visual processes. Before the War of 1914-18 it was customary in schools to give special classes for what was called "eye training", but since then the method has been discarded. It is undoubtedly in part a psychological problem, as are, in fact, all visual problems, and training undoubtedly induces alertness in making particular types of observation. In the discussion, for example, reference was made to the very high accuracy to which a trained workman could judge angles and other dimensions of an object. Another point was made that, in problems of discrimination and visual estimation, the boundary line between physiology and psychology is rather vague, so that the possibility that training may modify the response of the eye as well as the reaction in the brain ought not to be overlooked.

There is obviously a great deal still to be learnt about how the eye works and how to apply the information that is available. The problem is a vast and intricate one and the conference served to bring different interests together to form a pool of knowedge, knowledge that has somehow to be passed on to the whole industrial community.

\section{CANCER RESEARCH IN GREAT BRITAIN}

$T$

THE eighteenth annual report of the Grand Council of the British Empire Cancer Campaign (11 Grosvenor Crescent, London) was issued in February. At the meeting at which the report was presented, it was stated that more cancer research had been carried on during the War than had been anticipated in 1939. The summary refers with justifiable pride to "the lead in cancer research which Britain is still giving to tha whole world". On account of this, appeals for financial assistance for the Cam. paign which had been discontinued at the beginning of the War will be made again.

The report itself has its familiar form, and shows that a considerable amount of work has been carried out in Great Britain, though there is little research to report from the Dominions. During the year which ended last summer the campaign expended almost $\mathfrak{1 4 5 , 0 0 0}$ in supporting research workers and institutions.

Advances in our knowledge of cancer have been made in many countries. Important contributions 
have been made in the United States to our understanding of the nature of filterable tumours and the inheritance of cancer in mice. Japanese workers have made important discoveries on the experimental induction of liver tumours. But "the study of cancerproducing and cancer-inhibiting substances is predominantly a British study". Perhaps the most interesting carcinogenic agents are those which occur in living organs. The first descriptions of such substances came from Russian workers. Examination of bile and liver tissues has been carried on in Great Britain, and tumours have been produced in mice by injection of extracts of human livers.

The testing of more than seventy compounds related to known carcinogenic compounds during the last three years at the Royal Cancer Hospital has shown that the capacity to produce skin tumours by painting does not always run parallel with the capacity to produce sarcomata by subcutaneous injection.

Progress has been made in the study of the metabolism and excretion of carcinogenic hydrocarbons. The fluorescence of these compounds makes it easy to follow their excretion. At the Royal Cancer Hospital it was shown that when $1: 2: 5: 6$ dibenzanthracene is fed to rabbits it is excreted in the urine as a dihydroxy derivative, and later American work has confirmed and extended this finding. Prof. F. Weigert and Dr. J. C. Mottram have shown that the fluorescence of benzpyrene varies from blue to violet in animals injected or painted with the compound. The blue fluorescence is seen in the bile of treated animals. At the Glasgow Royal Cancer Hospital, work on the metabolism of benzpyrene indicates that a hydroxy benzpyrene is excreted in the bile of animals injected with the hydrocarbon.

Workers at Leeds have produced tumours of the bladder in dogs after very prolonged dosage of pure $\beta$-naphthylamine by mouth. This confirms the earlier work of Hueper in the United States, and indicates that $\beta$-naphthylamine itself is probably the primary cause of cancer of the bladder in dye workers. Careful research carried out in Newcastle-on-Tyne has shown that wood smoke such as is used for smoking food is not carcinogenic to animals.

Most carcinogenic compounds inhibit the growth of normal and malignant tissues, and the correlation between carcinogenicity and growth-inhibiting power has been thoroughly investigated at the Royal Cancer Hospital. Two compounds-1:2' azonaphthalene and $1: 2^{\prime}$ diamino $2: 1^{\prime}$ dinaphthyl-have been found to be inhibitory but noncarcinogenic. It is suggested that some compounds of this type might be tested clinically for treatment of cancer.

Animal tumours can be grown in tissue culture and often, on retransplanting into animals, lead to development of tumours. A mouse tumour grown in vitro in this way in Birmingham for more than eight months was able to produce tumours in mice and then lost this power of growing in vivo. In Glasgow a fowl tumour grown in tissue culture did not always produce tumours when inoculated into fowls. There is evidence that tumours while still growing in tissue culture may lose their ability to grow in animals.

Photomicrography of irradiated malignant tissues, using monochromatic ultra-violet light, shows the position and amount of nucleic acid material in cells. In eleven out of fifteen cases examined, a striking increase in nucleic acid in the cells occurred after irradiation. The increase in nucleotide material is not confined to malignant cells, but has also been observed in normal and hyperplastic tissues.

In spite of difficulties due to the War, progress in technique of therapy by radiological methods continues. At the Mount Vernon Hospital it has been shown that treatment of carcinoma of the vulva with a given dose $(1,200$ r.) is much more effective if given at high intensity ( $350 \mathrm{r}$. per minute) than if given at low intensity ( $20 \mathrm{r}$. per minute).

At St. Bartholomew's Hospital more experience has been gained in the clinical application of the million volt $X$-ray apparatus. An increasing number of patients is being treated and the results obtained suggest that it is particularly effective in treatment of cancer of the rectum, a site in which treatment by softer X-rays has not hitherto yielded satisfactory results.

Mr. E. N. Willmer in Cambridge has examined the effect of trypsin on cultures of chick heart fibroblasts. A I per cent solution of the enzyme had only slight toxic effects but caused the cells to round off. A more dilute $(0 \cdot 1$ per cent) solution caused the constituent cells of embryo chick heart tissue to fall apart. The separated cells were able to grow and form new colonies of cells.

Dr. A. W. Greenwood has continued to supply chicks and fowls to research workers investigating the pathology of fowl tumours. Careful observation and breeding of Brown Leghorn chickens has shown that there is considerable variation in susceptibility of this stock to the Rous No. 1 sarcoma. The inheritance of variation in susceptibility is being studied. The susceptibility in any one bird is not necessarily extended to all tumours. Thus a transplantable chemically induced tumour grows in birds from a strain resistant to the Rous No. 1 tumour agent.

Variation in reaction to the Rous tumour virus has also been encountered at the Middlesex Hospital, where the birds of a Light Sussex Plymouth Rock cross could not be immunized, while Brown Leghorn fowls readily develop immunity to concentrates of Rous sarcoma. The low resistance of the Light Sussex cross-bred fowls may be connected with the capacity to yield chemically induced filterable tumours which have occurred in these fowls at the Middlesex Hospital laboratories. The serum of susceptible fowls may be able to agglutinate the Rous virus without neutralizing it, while the serum of resistant fowls may contain neutralizing antibodies without agglutinins.

Many efforts have been made to demonstrate a virus in 'non-filterable' tumours. At the Glasgow Royal Cancer Hospital filterable and non-filterable tumours have been compared by inoculation of tumour material which has been ground with and without sand. Filterable tumours are still trans. missible after grinding with sand, but the infectivity of other tumours is destroyed by such treatment. Filterable tumours transmitted with ground tissue "grow in a diffuse manner with ill-defined edges, so that the muscle substance is deeply infiltrated over a wide zone". The non-filterable tumours grow from multiple foci, suggesting that they have developed from isolated cells or cell clumps; such tumours depend for their transmission on the inoculation of a sufficient number of viable cells. Work in the field laboratory at Sheffield indicates that the simultaneous injection of mouse tumour tissue treated with glycerol does not influence the incidence of tumours induced in mice by the injection of methyl cholanthrene. 
The Clinical Cancer Research Committee of the Campaign presents a report in which material collected in 1938 and 1939 , particularly with regard to uterine cancer, is considered in detail.

The body of work which is reported indicates that the impetus of cancer research in Great Britain even in war-time is considerable, and that with a return to peace-time conditions extremely rapid progress should be made.

E. Boyland.

\section{ECONOMIC VALUE OF THE COMMON STINGING NETTLE}

\section{By DR. C. R. METCALFE \\ Royal Botanic Gardens, Kew}

$T \mathrm{~T}$ is a well-known fact that the common nettle (Urtica dioica) yields a very strong bast fibre which was used in Great Britain until about 1860 for the manufacture of cloth. Since then its use has been discontinued because other cheaper, imported materials became available. In the past, nettles have been cultivated also in France and other parts of Europe for the production of fibre.

During the War of 1914-18, the Germans were quick to recognize the value of the nettle as a source of fibre. According to published information, 10,000 tons of wild nettles were estimated to be available in Germany. The collection of these was undertaken largely by children; transport being arranged in collaboration with the military authorities. The whole organization was controlled by the "Nesselfaserverwertungs-Gesellschaft" and the "NesselanbauGesellschaft" which operated from Berlin, while the "Bayerische Nesselfaser-Gesellschaft" had offices at Munich. The estimated yield was between 1,500 and 2,000 tons of fibre, valued at between two and three million marks. This was to be used chiefly in the manufacture of textiles. At the same time, 3,000 tons of food from the leaves and 3,000 tons of byproduct material suitable for use in paper and chemical factories were to be extracted. Other extracts included lignin, chlorophyll and potassium nitrate, while nettle products were even used in the manufacture of gas mantles ${ }^{1}$.

At the outbreak of the present War, the German Government immediately appealed to the general public to collect nettles once again ${ }^{2}$. Apparently the nettles are still being used with success, for it was reported from Stockholm in the Daily Express on June 8,1942 , that about 5,000 railway carriage loads of stinging nettles will be collected in Hungary this summer for use as raw material for textiles.

Although most of these facts have been known in Great Britain for many years, it is only recently that it has been possible to arouse any interest in nettle fibre in commercial circles. The availability of more familiar fibres, and other causes, have closed our eyes to the possibility of making use of a very common and troublesome weed. About two years ago, however, samples of nettle bast fibre were extracted at the Royal Botanic Gardens, Kew, and sent to another institution for certain experiments which were then in progress. Tests, which were then made, fully confirmed that the bast fibre is remarkably strong and that it consists of a very pure form of cellulose. Other tests on fibre extracted at Kew were also made at the Imperial Institute, where it was demonstrated that good-quality paper can be made from the bast fibre. Larger samples of nettle fibre were prepared in 1941, which were examined by paper-making firms in Scotland, and pronounced to be very satisfactory. From the World's Paper Trade Review of May 15, 1942 , it is learned that a Renfrewshire firm of papermakers is prepared to purchase 1,000 tons of nettles this summer at a minimum price of $£ 10$ per ton, and that another firm in Fife is willing to buy 200 tons for experimental purposes. In the same journal it is also stated that steps have been taken to cultivate several acres of nettles for the same purpose, care being taken to do this only on land which is unsuitable for other crops.

It must be emphasized that the samples extracted at Kew consisted only of the bast fibre; the wood fibre, which possesses quite different properties, was a waste product. Unfortunately, it is difficult to reduce the wood fibre to pulp, so that this material cannot be used unless new and less expensive methods of treating it can be devised. The bast fibre represents only about 8-10 per cent of the dry weight of the nettle stem, so it can be seen at once that a considerable amount of material is likely to be wasted unless methods of preparation can be improved, or an alternative use found for the by-products. It is also important to emphasize that the quantity of available nettles is never likely to be sufficient to satisfy more than a small fraction of the paper requirements of Great Britain. The most promising line, therefore, would appear to be to make goodquality paper for special purposes. Whether it would be economically possible in Great Britain to use nettle fibre for textiles as in Germany needs further investigation.

It is not generally known that differences in the standard of living in Great Britain and Central Europe respectively made it economically possible to import dried stinging nettles from the Continent before the War. This material was used for the extraction of chlorophyll, which is employed to give a green colour to soap and other toilet preparations and, to a limited extent, in medicine. Nettles are more favourable than other plants as raw material for this purpose owing to the ease with which the chlorophyll may be extracted, as well as to the desirable shade of green which it exhibits. A great deal of the chlorophyll used in Great Britain before the War was imported ready-made from the Continent. It will be interesting to see whether, after the War, economic conditions will be such as to enable or make it desirable for us to import this material again.

There is, meanwhile, an admirable opportunity to extract chlorophyll for export to those countries which, like ourselves, were previously supplied from the European Continent. The desirability of effective collaboration between those who eultivate nettles for fibre and those who wish to use the leaf for the extraction of chlorophyll is clear for all to see. We might also emulate the German skill in using Ersatz material by devoting any excess of leaves to the feeding of cattle, even if the well-known value of young nettles as human food fails to command much popular respect. It is interesting to note in this connexion that the protein content of the nettle is high.

1 Ulbrich, E., "Fasern" in "Ersatzstoffe aus dem Pflanzenreich" edited by L. Diels, Stuttgart, 1918, 318-87. Pp. 355-63 deal with the flbre of Urtica dioica.

2 Anon., Jute Abstracts, 3, 9, 235. 